\title{
A Review of Methodological Integration in Land-Use Change Models
}

\author{
Anh Nguyet Dang, Asian Institute of Technology, Pathumthani, Thailand \\ Akiyuki Kawasaki, Department of Civil Engineering, University of Tokyo, Tokyo, Japan
}

\begin{abstract}
Global change research communities are paying increasing attention to answering critical questions related to land-use change, questions which are at the root of many pressing socio-economic and environmental issues. In this regard, a huge number of models have been developed to support future land-use planning and environmental impact assessments of land-use change activities. Within land-use change models, methodological integration is recognized as an essential feature for a complete model, which can help to combine the strength of single modelling methods/techniques without inherent weaknesses. Despite the potential and remarkable growth of methodological integration in land-use change models, limited attention has been paid to this aspect of integration. In response to this, the authors' paper summarizes the current major land-use modelling methods/techniques, and explains the co-integration of these methods/techniques. In addition, they summarize the achievements, limitations and future trends in the use of the methodological integration approach in land-use change models.
\end{abstract}

\section{KEYWORDS}

Integrated Approach, Land-Use, Land-Use Change Model, Land-Use Management, Land-Use Modelling, Methodological Integration, Review

\section{INTRODUCTION}

The Millennium Ecosystem Assessment (MEA) (2005) revealed that the modification and conversion of land by humans is among the most important and major global changes of the last three centuries. During this time, half of the Earth's ice-free land surface has been transformed by man. Most of the remainder is managed for human purposes unpredictably in terms of pace, magnitude and spatial scale (Global Land Project, 2005a). The MEA found hardly any uses of land that did not have negative effects on ecosystem patterns and processes across the terrestrial biosphere, including on the water cycle (Sterling et al., 2012; Swartz et al., 2003), soil environment (da C Jesus et al., 2009) and biodiversity (Hof et al., 2011; Seto et al., 2012; Zorrilla-Miras et al., 2014). Changes of the land surface have also disturbed the balance of greenhouse gases and resulted in the Aledo effect, which ultimately has contributed to regional and global climate change (Cai et al., 2004; Chhabra et al., 2006; Pielke, 2005; Rindfuss et al., 2004; Steffen et al., 2005; Wu et al., 2014). 
Given continuous population growth, sustainable land-use management has become ever more essential to human life (Global Land Project, 2005b). The need for sustainable land-use management has resulted in the development of models that describe and explain the process of land-use change, predict future scenarios, and measure the impact of land-use activities (Turner et al., 1999; Veldkamp et al., 2001; Verburg et al., 2004). Currently, the principal aim of land-use science is to project changes to land-use, an aim which helps natural resource managers and decision-makers make long-term, comprehensive and sustainable plans (Ghaffarzadegan et al., 2011; Helming et al., 2011; Müller, 2003; Parker et al., 2003; Pontius Jr et al., 2001; Reidsma et al., 2011).

With the progress in computing power, the integrated approach has emerged as an important means by which to improve comprehensive understanding of land-use dynamics (Rotmans et al., 2001; Verburg et al., 2006). The integrated approach varies with the model purpose, for example spatial integration; sectoral integration; land use type integration; economy-society-environment integration and methodological integration etc (Briassoulis, 2000). In this review, we concentrate on methodological integration, which is one of six essential features for a complete land-use change model as stated by Verburg et al (2004). Despite of its importance, there is very limited attention has been given to methodological integration within land-use change models. Methodological integration in land-use change models can be defined as the combination of more than one technique/method to better develop simulation algorithms in land-use change models. This approach gives detailed coverage of several essential aspects of the land-use change process, something that single methods fail to do. Methodological integration was analysed in the reviews of Briassoulis (2000); Heistermann et al. (2006), Koomen et al. (2011), and Michetti (2012). Nevertheless, these reviews focused only on the integration within operational models, which was established as a model package. Indeed, a large number of researchers have developed their own models rather than use operational models, given restricted scope and scale in the application of operational models (data and knowledge requirements, for instance). Reviews that focus only on the operational model do not cover the diversity of the methodological integration in land-use change models.

To fill this gap in knowledge, we reviewed methodological integration in both operational nonoperational land-use change models. We summarized and synthesized knowledge and information from previous studies in the field to explore four key areas: (1) major modelling methods/techniques and their strength and weakness; (2) methodological integration in land-use models; and (3) the achievements and limitations of the methodological integration and future trends in this regard. A search of Scopus and Web of Science revealed that research in the field of land-use change began in the 1960s, and has continued since then. We consulted 30 of the most-cited articles and books written in the research field during this period. The references in these sources suggested further sources to examine. Our review paper is aimed at researchers or modellers who intend to improve their models or are looking for new research approaches but do not have much time to review a wide range of land-use change model research. Just by referring to our paper, readers will have a general picture and can find the appropriate methodological integration for their current and future works.

\section{CURRENT LAND-USE MODELLING METHODS/ TECHNIQUES: STRENGTH AND WEAKNESS}

An important consideration in model building is the selection of appropriate methods and techniques. The methods and techniques needed depend entirely on the purpose of the model or the research questions under investigation. In this section, we analyse the strength and weakness of major modelling methods/techniques currently employed in land-use change models. In addition, origin and general characteristics of methods/techniques are also introduced. In Figure 1, the development of methodological integration in land-use change models was summarized with a relative timing. 


\subsection{Cellular Automata Model}

Cellular Automata (CA) was introduced by Ulam and Von Neumann in the 1940s to investigate the behaviour of complex self-reproducible systems. Then Tobler (1979) was the first person to apply $\mathrm{CA}$ in the field of geography. The strength of CA is that it is one of the simplest among methods suitable for modelling land-use change in a spatial and detailed fashion (Lagarias, 2012; Lambin et al., 2006; Yu et al., 2010). It has been used in many land-use change models (Jantz et al., 2005; Pinto et al., 2007; Stevens et al., 2007; Subedi et al., 2013). CA is based on mathematical theories of self-reproduction in automata and stochasticity within the two dimensional cellular-grid environment (Hewitt et al., 2014). The five elements of CA are cell space, cell states, time steps, transition rules, and neighbourhood, which influences the central cell (Moreno et al., 2009). After determining the number of cells that change in each step of the simulation, transitional rules are used to explain landuse changes based on the state of cells in the vicinity (Maria de Almeida et al., 2003). The transitional rules can be expert-based or derived from statistical analysis (White et al., 2000).

The popularity of CA rose with developments in remote sensing and GIS. Along with the benefits of interactive visualization and quantified outcomes, CA integrates easily with the GIS environment and remote sensing data (Han et al., 2009; Li et al., 2000; Sui et al., 2001). A widely used CA operational model is SLEUTH (Slope, Land use, Excluded land, Urban extent, Transportation and Hillshade), which has been successfully applied worldwide for over 15 years (Chaudhuri et al., 2012; Clarke, 2008). In SLEUTH, the land behaves like a living organism and is trained by growth transition rules (Herold et al., 2003). The multiple simulations of growth within SLEUTH are generated by the Monte Carlo theory (Jantz et al., 2005). The Countervailing Cellular Automata (CVCA) model also follows CA concepts. CVCA is defined by grid space, neighbourhood effect, a set of transition rules, and a time step iteration. In CVCA applications for land-use research, basic cells usually correspond to land-use types and transition rules to the processes associated with land-use change. The CVCA code is closely linked to SLEUTH and can work in conjunction with it (Silva et al., 2008).

CA models, however, focus more on the simulation of spatial patterns rather than interpreting the temporal process of socioeconomic variables (Hu et al., 2007). This bottom up approach might not be suitable for land-use systems where the area of land-use change is at least partly determined by demand for the activity carried out in the cells. The simplicity of CA allows it to integrate with other methods/techniques to produce a comprehensive model that encompasses the multiple effects of socioeconomic driving forces (Clarke et al., 1998; Herold et al., 2003; Li et al., 2000). These forces are discussed in the following sections.

\subsection{Markov Chains Model}

The application of Markov Chains to predict land-use change was proposed as early as 1965 (Briassoulis, 2000; Houet et al., 2006; Irwin et al., 2001). Using a 'stationary' assumption, whereby the temporal rate of change and actual change stay the same, Markov Chains employ matrices to present multi-directional land-use change in all mutually exclusive land-use categories (Lantman et al., 2011). For example, three land-use categories make for nine possible changes in land-use. The transition matrix can be created using expert knowledge or by drawing on history and maps and comparing land-use change over time (Muller et al., 1994). The transition matrix generates the transition probability, which is the probability of land shifting from one land-use type to another. In the earlier stages of land-change analysis, Markov Chains were used to estimate the total area of change with regard to particular forms of land-use, for example, urbanization in agricultural areas (Muller et al., 1994). More recently, analysis that uses Markov Chains has been combined with GIS to create a tool for visualizing and projecting the probabilities of land-use change (Ma et al., 2012; Munthali et al., 2011), assessing the relation of land-use change and climate change (Freier et al., 2011), and calculating the ecosystem service value of land-use (Luo et al., 2014).

The applicability of Markov Chains in land-use change modelling is promising because of its ability to quantify not only the states of conversion between land-use types but also the rate of 
conversion among the land-use types (Subedi et al., 2013). In addition, Markov Chains can help to cover a larger spatial scale (Weng, 2002). However, Markov Chains modelling method is purely nonspatial; only cell states are considered and no attention is paid to the influence of neighbour cells.

\subsection{Economic based Model}

Economic based models of land-use change originated in the land rent theories of Von Thünen, proposed in 1826 (Helming et al., 2011). These theories referred to distance and transportation costs to explain land-use patterns and land prices. In general, economic science posits that resources will be allocated so as to maximize profit. The same notion can be applied to land-use. Economic based land-use change models incorporate the assumption that landowners will use the land in such a way as to maximize its utility and their expected returns. Land is allocated according to economic variables such as food consumption and prices, travel times and access to markets. Most economic based models of land-use change are equilibrium models, meaning that they seek to explain land allocation through reference to demand-supply structures (Michetti, 2012). GTAP, AgLU, and FASOM are widely used economic based models that employ the equilibrium theory to estimate land demand (Hertel, 1997; Michetti, 2012).

The strength of these economic models, which incorporate assumptions about future economic activity, is their description and quantification of drivers that affect demand. These models provide a structure by which to represent the competition between different sectors, changes in management and technology, and the shifts in demand that result from trade and policy interventions (Heistermann et al., 2006).

There are drawbacks to economic based models. They do not take into full account the geographic location of land (Verburg et al., 2003). Furthermore, results produced by economic based models rest on the assumption that economics is the main driver of land-use change: such models have tended not to account for climate and biophysical factors. Land-use change is a multidisciplinary issue, not attributable to economic variables alone. In addition, economic models assume homogeneity of all conditions within the study area and cannot account for impacts of land use change on land productivity as result of expansion on or abandonment of marginal lands.

\subsection{Statistical based Model}

Statistical based methods are used to derive the mathematical relationship that links the probability of land-use change with a wide range of variables such as population growth, topography and transportation corridors. These relationships are normally obtained through linear regression, binomial logit and multinomial logit models, and the logistic regression model (Takamatsu et al., 2014). The CLUE model, for instance, uses multiple regression to simulate recent and future changes in land-use patterns. The CLUE framework has been adjusted and applied to different study areas, using various versions of the model: CR (Veldkamp et al., 1996), CLUE-S (Verburg et al., 2007; Wassenaar et al., 2007) and Dyna-CLUE (Lourdes et al., 2011). Other statistical based models are Land-scanner (Hilferink et al., 1999), and FORE-SCE, which uses logistic regression to develop probability-ofoccurrence surfaces for land-cover types (Sohl et al., 2008).

Statistical approaches have strength in modelling individual behaviours. These approaches can readily identify the influence of independent variables and also provide a degree of confidence regarding their contribution. In many cases, these models fit spatial processes and land use change outcomes reasonably well (Hu et al., 2007)

Many integrated land-use models are based on an extrapolation of trends in land-use change, determined through the use of a regression. Therefore, these models are not necessarily suited to longer-term scenario analysis as they are based on a limited period, usually one or two decades. In addition, statistical approaches assume the data to be statistically in-dependent (Lesschen et al., 2005) 


\subsection{Artificial Neural Networks Model}

Artificial neural networks (ANNs) were first developed by Rosenblatt (1958), who explained the perceptron by modelling the brain's interconnected system of neurons. ANNs consist of layers and neurons, which simulate the structure of human brains (Fu, 1995). Through computer applications, ANNs have been used in disciplines such as medicine, economics, and mechanical engineering (Aisa et al., 2008; Pijanowski et al., 2002). In the last few years, with advances in computing performance and the increased availability of powerful and flexible software, ANNs have been used in land-use modelling (Almeida et al., 2008; Tayyebi et al., 2011). In terms of predicting land-use change, ANNs have been applied in four phases (Pijanowski et al., 2005). First, data variables are assigned to input units (nodes), with the variable values of land-use change typically observed from historical data. Second, the network is trained using a subset of inputs. Third, the neural network is tested using the full input data set. Fourth, information from the neural network is used to forecast change (Pijanowski et al., 2002). The Land Transformation Model (LTM), which couples ANNs with GIS, was developed in 1995 to forecast land-use change over large regions (Pijanowski et al., 1995). In the LTM, GIS is used to develop the spatial predictor drivers and perform spatial analysis on the results (Pijanowski et al., 2002).

A significant advantage of neural networks is the ability to combine data from different sources into the same classification. This model also has the strength of linking changes in land-use to a variety of socioeconomic, political and environmental factors. ANNs are especially useful for policymakers interested in the optimal configuration of an area based on different policy goals (Eric et al., 2007).

Nevertheless, an ANN is usually treated as a "black-box" with which the weights are uninterpretable due to the presence of hidden layers and the nonlinearity of the activation function. Neural nets are not self-explanatory; there are no standard tests that can measure the degree of variability in the outputs explained by certain inputs or the significance level of the predictions. An ANN with a highly complex architecture and optimum network geometry (e.g. the number of hidden layers and the number of nodes in hidden layers) may perform well with one data set and very poorly with another. Time is required to adequately train and test neural networks. The learning curve is steep, and only developers with experience will become more efficient using this technique (Changhui et al., 1999).

\subsection{Agent-based Analysis Model}

Land-use change is a complex process that includes actors at different social and spatial levels. Hence, interest in the application of agent-based and multi-agent system tools (human land-use decisions) to model land-use change has increased rapidly (Evans et al., 2004; Filatova et al., 2013; Kelley et al., 2011; Valbuena et al., 2010). An agent may be a land manager, a social organization such as a village assembly or local government body, or even a neighbouring country (Parker et al., 2001). Agents' preferences can be defined by expert judgment or through questionnaires (Lantman et al., 2011).

This method/technique allows modellers to capture the specialized knowledge of stakeholders and, thus, to provide a tool for scenario analysis and knowledge discovery (Fennell, 2013). Matthews et al. (2007) noted that agent-based analysis complements other techniques. However, the nature of analysis in agent-based models means that some important detail is lost. These models tend to concentrate on the most readily apparent and easily quantifiable aspects of land use, without accounting for such factors, outmigration, changes in techniques and input use, and the influence of regional and global economic variables.

\subsection{System Dynamic Model}

System Dynamic (SD) is a simulation technique originally proposed by Jay W. Forrester in the 1950 s to achieve systems thinking in solving complicated management problems. The SD modelling technique uses stock flows and feedback loops to understand how physical processes, information 
flows and managerial policies interact to create dynamic variables of interest (Liu et al., 2013), and to search for alternative policies (Costanza et al., 1993).

In 1972, Meadows used the SD theory to develop Limit to Growth models to assess the impact of pollution, population growth and resource use, including that of land (Donella H. et al., 1972). Voinov et al. (1999) designed the Patuxent Landscape Model, a SD model, to simulate fundamental ecological processes: the model interacts with a component that predicts land-use patterns for the Patuxent watershed in the United States. A well-known SD in land-use research is SALU, a model of land-use change for the Sudano-sahelian countries of Africa. The SALU model reflects the expansion of agricultural land, a process driven by demand. The model works on the basis of a ranking that accounts for climatic, physical and economic factors (N. Stephenne, 2001).

The Economic Systems Land Use Management System Dynamics Model (SLUMSD) is also based on the conceptual dynamics framework (Yu et al., 2003). Systems thinking is used to develop dynamics of sustainable land-use management in a river basin, with consideration given to human activities and land, water and air resources. Results show that the SLUMSD model can help those responsible for land-use management decisions. Shen et al. (2009) developed a SD model for sustainable land-use planning and development in Hong Kong, while Yu et al. (2011) modelled land-use change in Daqing City, China.

The land-use process is never static. It changes constantly in response to the dynamic interaction between drivers and the feedback to these drivers from land-use change (Lambin et al., 2003). Compared with statistical frameworks, SD models try to simulate temporal changes in the landuse process in order to address the interactions between processes and driving factors in different scenarios. The models can capture the effects of new land-use policies and, through the incorporation of different factors, predict future uses of the land. As the model is not spatially explicit and predicts only aggregated values of land-use change, hence The major weakness of SD is the lack of sufficient spatial analytical capabilities (Costanza, 1990; N. Stephenne, 2001; Stéphenne et al., 2001).

\section{METHODOLOGICAL INTEGRATION IN LAND-USE CHANGE MODELS}

Capturing the complexity of land-use change is one of the most important issues in land-use change modelling (Ronneberger et al., 2009). As each single research methodology is a part of a broader context, no single model captures all the characteristics of land-use change (Castella et al., 2007; Van Duivenbooden et al., 1998; Verburg et al., 2001). In light of that, the integrated approach, including methodological integration aspect, has emerged as the most promising approach for reconciling the complexity and dynamics of land-use change (Lambin, 1994; Rounsevell et al., 2012), projecting alternative pathways into the future, and conducting experiments that test our understanding (Veldkamp et al., 2001). Combining the best aspects of different methods/techniques helps cover various disciplines (Eric et al., 2007), mutual relationships and link social science with geographical data to represent the processes driving changes to land systems and land allocation (Breuer et al., 2006; Subedi et al., 2013).

The dimension of methodological integration is not the same in different models. Michetti (2012) divided the link within models into off-line runs (the output of one model used as the input to a second model), soft-link (the same process as off-line runs but accounts for feedback effects and model integration until simultaneous convergence between the two models is reached) and hard-link (uses a reduced-form model, more detailed and more aggregated; assures long trend and consistent dynamics with immediate feedback) based on different degrees of coupling complexity. Heistermann et al. (2006) reviewed a combination of geographic and economic techniques, but their review did not cover all the integration combinations involved in land-use models. The large diversity in methodological integration that has evolved over recent years has prompted the authors to assess the overall picture. In this section, we detail various methods of methodological integration employed 
Table 1. The methodological integration within land-use change models

\begin{tabular}{|c|c|c|c|}
\hline No & Type of integration & Operational model & Non-operational model \\
\hline 1 & $\begin{array}{l}\text { Economic and statistical based } \\
\text { models }\end{array}$ & $\begin{array}{l}\text { KLUM-GTAP (Ronneberger et al., } \\
\text { 2009); CLUE-GTAP (Britz et al., } \\
\text { 2011); MAGNET - CLUE (Rutten } \\
\text { et al., 2014) }\end{array}$ & \\
\hline 2 & $\begin{array}{l}\text { Economic based models and } \\
\text { Cellular Automata }\end{array}$ & $\begin{array}{l}\text { IMAGE- GTAPEM (Letourneau et } \\
\text { al., 2012; Strengers et al., 2004) }\end{array}$ & \\
\hline \multirow[t]{2}{*}{3} & $\begin{array}{l}\text { Markov Chains and Cellular } \\
\text { Automata }\end{array}$ & $\begin{array}{l}\text { IDRISI Paegelow et al. (2008) } \\
\text { Poska et al. (2008), Thapa et al. } \\
\text { (2011), Adhikari et al. (2012), and } \\
\text { Kityuttachai et al. (2013) } \\
\text { Dinamica EGO(Mas et al., 2014; } \\
\text { Thapa et al., 2011) }\end{array}$ & $\begin{array}{l}\text { Bura et al.(1997); Jenerette et al. } \\
\text { (2001); Houset et al. (2006), Sun } \\
\text { et al. (2007); Fan et al. (2008), } \\
\text { Kamusoko et al (2009); Mitsova } \\
\text { et al. (2011); Guan et al (2011); } \\
\text { Zhang et al.(2011); Sang et al. } \\
\text { (2011); Zhou et al. (2012), Chen } \\
\text { et al. (2013); Subedi et al.(2013); }\end{array}$ \\
\hline & $\begin{array}{l}\text { Markov Chains and Cellular } \\
\text { Automata, Statistic }\end{array}$ & & $\begin{array}{l}\text { Peterson et al. (2009), Lei et al. } \\
\text { (2012) and Jokar Arsanjani et al. } \\
\text { (2013) }\end{array}$ \\
\hline 4 & $\begin{array}{l}\text { Artificial neural networks and } \\
\text { Cellular Automata }\end{array}$ & & $\begin{array}{l}\text { Pijanowski et al. (2005); Charif } \\
\text { et al.(2012); Lee et al. (2013); } \\
\text { Ding et al.(2013) }\end{array}$ \\
\hline \multirow[t]{2}{*}{5} & $\begin{array}{l}\text { Agent based and Cellular } \\
\text { Automata }\end{array}$ & $\begin{array}{l}\text { CORMAS (Le Page et al., 2000), } \\
\text { and LUPAS (Landuse planning } \\
\text { and analysis system) (Roetter } \\
\text { et al., 2005; Van Paassen et al., } \\
\text { 2007); SWARM (Perez et al., 2012; } \\
\text { Schaldach et al., 2011); ASCAPE } \\
\text { (Eeftens et al., 2012). }\end{array}$ & Parker et al. (2003) \\
\hline & $\begin{array}{l}\text { Agent based and Cellular } \\
\text { Automata, statistic }\end{array}$ & $\begin{array}{l}\text { ABMs and CLUE Castella et al. } \\
(2007)\end{array}$ & Filatova et al (2013) \\
\hline 6 & $\begin{array}{l}\text { System Dynamic and Cellular } \\
\text { Automata }\end{array}$ & $\begin{array}{l}\text { LUMOS (de Nijs et al., 2004; } \\
\text { Geertman et al., 2007). } \\
\text { LUSD He et al. (2005) }\end{array}$ & $\begin{array}{l}\text { Carneiro et al. (2004); Deal et } \\
\text { al. (2004), Shen et al. (2007), } \\
\text { Gharib (2008); Han et al. (2009); } \\
\text { and Lauf et al. (2012). }\end{array}$ \\
\hline 7 & $\begin{array}{l}\text { System Dynamic and statistical } \\
\text { analysis }\end{array}$ & $\begin{array}{l}\text { CLUE and the GAMS-based } \\
\text { Village Farm Household Model } \\
\text { (VFHM) (Gibreel et al., 2014) }\end{array}$ & $\begin{array}{l}\text { Zhan et al. (2007); Luo et al. } \\
\text { (2010) and Zheng et al. (2012). }\end{array}$ \\
\hline
\end{tabular}

in land-use models, both operational and non-operational. The methodological integration within land-use change models is presented in Table 1.

\subsection{Economic and Statistical based Models}

Most economic models are developed without spatial determinants, which limits their ability to answer "where" questions (Verburg et al., 2006). Hence, economic models cannot link land-use demand with the impact on land-use systems. More recent work in land-use modelling has focused on furthering integration between economic based models and statistical techniques. Economic theory is used to analyse market and policy factors in order to quantify demand for and supply of land-intensive commodities, while statistical analysis is used with regard to the allocation of land-use types (Heistermann et al., 2006). 
Of those models which integrate economic and statistical methods, CLUE-GTAP (Britz et al., 2011) combines two independent models - CLUE and GTAP. Global Trade and Analysis (GTAP) the economic based model - is used to calculate changes in land-use demand. The standard GTAP model is characterized by an input-output structure based on regional and national input-output tables (Verburg et al., 2008). The most important inputs of the GTAP model are the demographic, macroeconomic and technological developments and policy assumptions. The GTAP model calculates changes in land demand by maximizing a profit function for a representative producer for each sector of a country or region (van Meijl et al., 2006). CLUE uses logistic regressions to identify location suitability and simulate the competition and interactions between different land-use types (Verburg et al., 2008). In other word, CLUE was used to translate these demands to land use patterns

KLUM-GTAP (Ronneberger et al., 2009) operates similarly. KLUM and GTAP-EFL is employed to assess the integrated effects of climate change on global cropland allocation, and the implications climate change poses for economic development. The GTAP-EFL model, an extended version of the Global Trade Analysis Project model, determines regional demand for crops and pasture. The Kleines Land Use Model (KLUM) is a scale-independent global agricultural land-allocation model. The land-use choice module chooses the set of alternatives with the highest utility by means of logistic regression, with the resulting allocation grid based. Allocation decisions are not based on allocation rules which aim to satisfy a defined demand, but on a dynamic allocation algorithm, which is driven by profit maximization under the assumption of risk aversion and decreasing returns to scale. This means that land allocation under the KLUM model is firmly based on economics and that the validity of long-term predictions is ensured.

A recent example of an economic-statistical model is the combination of Modular Applied GeNeral Equilibrium Tool (MAGNET), a global economic simulation model, with the model CLUE (Rutten et al., 2014). MAGNET is based on GTAP. The main output of MAGNET is a set of economic indicators that cover economic change, sector growth, employment, food consumption, prices and trade. Based on assumptions of economic growth and development, MAGNET also determines the demand for land. MAGNET is unable to show the spatial dynamics of land-use change, an output that is covered by CLUE.

\subsection{Economic based Models and Cellular Automata}

The Integrated Model to Assess the Global Environment (IMAGE) (Letourneau et al., 2012; Strengers et al., 2004) combines different sub-models adopted from a wide range of disciplines. The land-cover sub-model, an allocation tool based on CA, allocates the commodity demands. Land demand is calculated according to land potential by the Agri-cultural Economy Model. However, the economic demand module is theoretically weak as trade and market interactions are not dynamically represented. The Europe's rural areas (EURURALIS) project aims to improve this weakness by coupling the IMAGE model to GTAPEM (a GTAP model that draws on the Organization for Economic Cooperation and Development (OECD) Policy Evaluation Model (PEM), a version of the standard GTAP model, to calculate production of food and animal products. A management factor is also incorporated. IMAGE allocates land to satisfy a given demand using land productivities that are updated by managementinduced yield changes as determined by GTAP. The advantage of coupling the two comprehensive models lies in the production of a detailed and comprehensive picture. However, there is a risk of redundancies and inconsistencies given that some processes, such as the allocation of land, are covered in both models.

\subsection{Markov Chains and Cellular Automata}

The simplest Markov Chains modelling method is purely non-spatial; only cell states are considered and no attention is paid to the influence of neighbour cells. In order to take account of neighbouring states and spatial allocation in the modelling process, Markov Chains and CA are combined. The Markov Chains process, based on transition matrices, controls temporal change among land-use types, while 
CA models, using local rules that consider neighbourhood configuration and transition potential maps, control spatial pattern change (Pontius et al., 2005). In this combination, spatially-explicit transition probabilities of land-use change depend on land location and neighbourhood influences. Mitsova et al. (2011) summarized the five steps of the Markov Chains - CA model (Markov-CA): (1) a Markov Chains transition matrix establishes the transition frequency of each cell within a specific land-use class; (2) multi-criteria evaluations determine the suitability and location of transitioning cells with CA; (3) numbers of iterations are assigned; (4) scenarios are developed; (5) model validation.

The Markov-CA model is reinforced by GIS, which helps to minimize difficulties in data processing and the limitation of spatial resolution. GIS is used to define initial conditions, assign parameters to the Markov-CA model, calculate transition matrixes, and determine neighbourhood rules (Kamusoko et al., 2009). GIS based Markov-CA models are proven to model land-use change with a high degree of accuracy (Guan et al., 2011; Subedi et al., 2013), especially with regard to urban growth projection (Mitsova et al., 2011; Zhang et al., 2011), and have been applied widely: Jenerette et al. (2001), Bura et al.(1997), Houset et al. (2006), Sun et al. (2007), Fan et al. (2008), Kamusoko et al. (2009), Sang et al. (2011), Zhou et al. (2012), Chen et al. (2013). The Markov-CA model is the foundation of the Integrated GIS and Remote Sensing Software Developed (IDRISI) program, which was employed by Paegelow et al. (2008), Poska et al. (2008), Thapa et al. (2011), Adhikari et al. (2012), and Kityuttachai et al. (2013). Another Markov-CA model is Dinamica EGO (Environment for Geo-processing Objects), which simulates landscape dynamics using Markov Chains to determine the quantity of change and the CA approach to the reproduction of spatial patterns (Mas et al., 2014; Thapa et al., 2011).

In order to develop a more efficient hybrid model, Peterson et al. (2009), Lei et al. (2012) and Jokar Arsanjani et al. (2013), combined logistic regression with the Markov-CA model. In this model, logistic regression was utilized to create a probability surface and to determine the most probable sites for development, while Markov Chains were used to measure/calculate change. CA is a tool which allocates probable changes under predefined conditional rules. The hybrid Statistical analysis-MarkovCA model has been shown to offer certain advantages compared with traditional analysis techniques.

\subsection{Artificial Neural Networks and Cellular Automata}

ANNs have recently been included in the domain of CA simulations. The ANNs-CA model can help to overcome the problem of transition rules in a single CA method ( $\mathrm{Li}$ et al., 2002). When multiple land-use categories are presented, the transition rules of CA models become substantially more complicated as the simulation involves the use of a much larger set of spatial variables and parameters.

The ANNs-CA model determines the transition probabilities of multiple land-use categories by using multiple output neurons under the ANNs concept. The model copes with the complex relationships between variables because ANNs have non-linear mapping abilities that deal with poor and wrong data. This integration is especially useful where the simulation of complex systems involves many parameters, as is the case with land-use systems (Charif et al., 2012; Ding et al., 2013; Lee et al., 2013; Pijanowski et al., 2005).

\subsection{Agent based and Cellular Automata}

Agent-based methods are combined with CA modules to form Agent-based Models (ABMs). Agent-based methods use rules that define the relationship between agents and their environment and determine the sequencing of actions in the model. CA modules represent the landscape under study, including a variety of spatial processes and influences relevant to land-use change (Parker et al., 2003). By combining agent-based techniques with spatial models and linking the behaviour of individuals to the behaviour of groups, scale dependencies can be explored in detail. These models are useful for representing cross-scale interactions and feedbacks, bottom-up and top-down, as agents are associated with a location in geometrical space (Berger, 2001). The involvement of agents also makes 
it possible to simulate emergent properties that may exert a significant influence on the behaviour of systems in the longer term. This is not a feature of most mono-discipline models.

Parker et al. (2003) simulated the evolution of a system of settlements by integrating CA with an agent-based approach. One of the most influential ABM models is Swarm (Perez et al., 2012; Schaldach et al., 2011). This model has inspired other ABM toolkits such as the Recursive Porous Agent Simulation Toolkit (RePast) (Brown et al., 2005; Xie et al., 2007), Ascape (Eeftens et al., 2012), Common-pool resources and multi-agent systems (Cormas) (Le Page et al., 2000), and the Landuse planning and analysis system (LUPAS) (Roetter et al., 2005; Van Paassen et al., 2007).

ABMs also involve other modelling techniques, including analytical and statistical (Filatova et al., 2013). This can enhance analysis of the processes and patterns of land-use change. To improve estimates of the influence of various drivers of land-use change in a mountain area of Vietnam, Castella et al. (2007) integrated ABM and CLUE.

\subsection{System Dynamic and Cellular Automata}

The ability of the SD model to represent the spatial process is weak because it cannot cope with a mass of spatial data and does not describe and model the distribution and situation of spatial factors (Zhang, 1997). At the same time, macro-scale political, economic and cultural driving forces, which exert an important influence on land-use change, are represented poorly by CA, a "bottom-up" model. For this reason, the Dutch National Institute for Public Health and the Environment (RIVM) developed the Environment Explorer (part of LUMOS, the Land Use Modelling System toolbox managed by the Netherlands Environmental Assessment Agency). This model is structured and operated on three spatial levels. At the national level, SD is used to determine the area of land needed for residential, commercial, industrial and recreational use. This is done by analysing the interaction of six main economic sectors: agriculture, glasshouses, industry, commerce, service and recreation. At the regional level, a spatial interaction technique is employed to model the localization of land-use demand, with the Netherlands subdivided into forty regions. A calculation is made to determine the type and extent of land-use, measured in hectares, in each region. At the local level, CA provides for a dynamic allocation of regional spatial claims within a grid of cells. This micro-model calculates transition potentials at the local scale for each step in time (one year), cell, and type of land use (de Nijs et al., 2004; Geertman et al., 2007).

He et al. (2005) developed the Land-use Scenario Dynamics model (LUSD), which integrates SD models and CA to predict changes to land-use in China over the next 50 years. The basic premise of LUSD is to use SD models to model land-use demand at the regional and national levels, then to allocate land use at a local level. Consideration is given to land-use suitability, inheritance, and the neighborhood effects of the CA model in balancing land-use demand and supply. The application of LUSD in China suggests that the model reflects the complex behaviours of various land-use systems, to some extent at least, and is a useful tool, through the integration of "bottom-up" CA models and "top-down" SD models, for assessing the potential impact of land-use on ecosystems. Han et al. (2009) devised an integrated SD-CA model for urban growth research in Shanghai. They found that the model proved competent in monitoring and projecting the dynamics of urban growth. Other studies that follow the same framework include those of Carneiro et al. (2004), Deal et al. (2004), Shen et al. (2007), Gharib (2008) and Lauf et al. (2012).

\subsection{System Dynamic and Statistical Analysis}

Zhan et al. (2007), Luo et al. (2010) and Zheng et al. (2012) describe an integrated methodology in which the CLUE model is combined with a SD model to analyze land-use dynamics. The SD model covers the temporal heterogeneity of fundamental changes in macro-economics, demographics and technology, and those changes to economic policy that influence land-use demand and supply in specific regions. The CLUE model simulates land-use change, with consideration given to land-use suitability, spatial policies and the restrictions that satisfy the balance between land-use demand 
Figure 1. Relative timing: the development of methodological integration in land-use change models

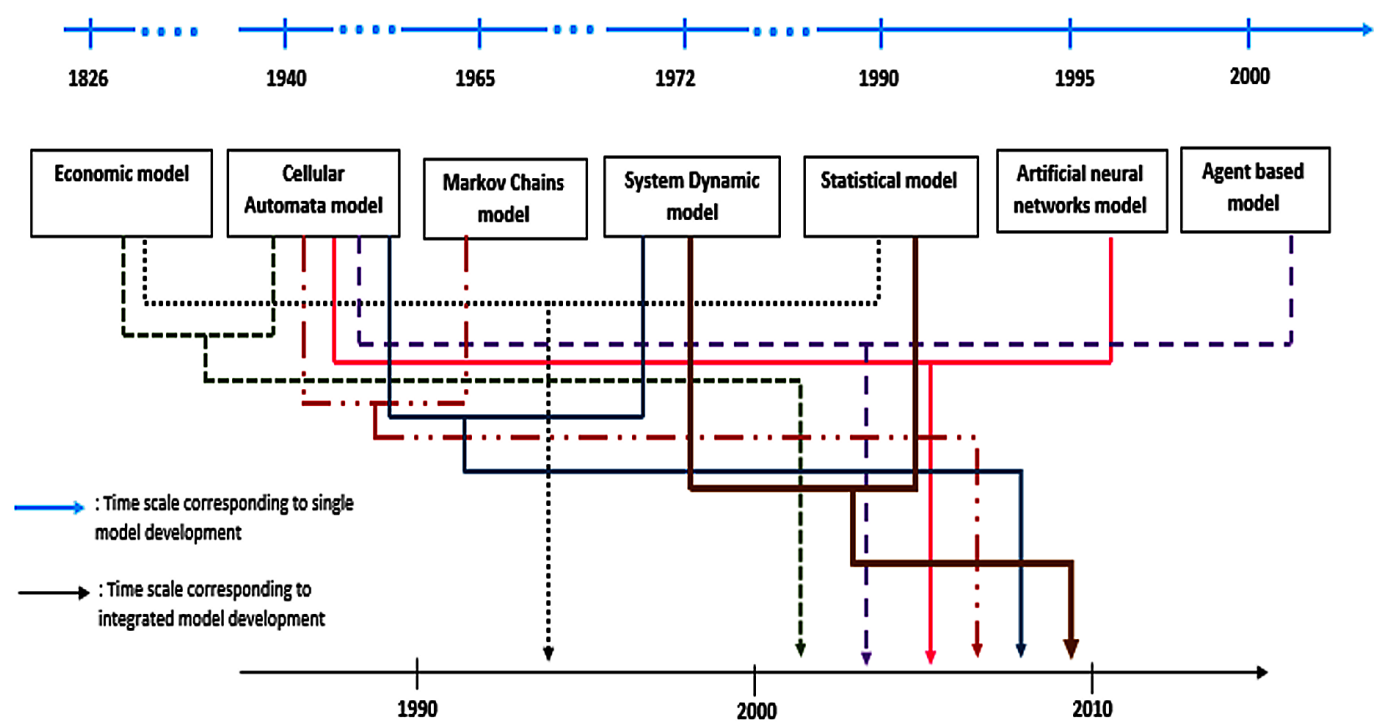

and supply. This SD-CLUE combination is able to reflect the complex behavior of land-use systems at different levels, to some degree at least, and is a useful means by which to analyze the complex factors that drive changes to land-use (Luo et al., 2010). Recently, an integrated model was developed (Gibreel et al., (2014) that combines CLUE and the GAMS-based Village Farm Household Model (VFHM), which is SD based. Given a set of goals and constraints, this model can determine the optimal allocation of land, labor and capital. CLUE was used to simulate land-use change based on empirically quantified relations, with logistic regression employed to establish the relationship between land use and the factors that drive change (Gibreel et al., 2014).

\section{DISCUSSION}

In this part of the paper we discuss the achievements of methodological integration in land-use change models, together with the challenges, and analyse future trends with reference to the spatial and temporal dimensions of land-use systems.

\subsection{Achievement of Methodological Integration in Land-use Change Models}

Methodological integration achievements made include (1) solving of problems of temporal and spatial scale, and (2) covering a multi-discipline and multi-scale approach.

\subsubsection{Solving Problems of Temporal and Spatial Mismatches}

Methodological integration can help resolve spatial and temporal mismatches in different ways. The involvement of agent-based within a complete model linking households with policy making process can help reduce the temporal gap in the policy making process (Rindfuss et al., 2004). Spatial regression techniques have solved spatial scale mismatches between the artificial imposition of rectangular boundaries on grid cells and behavioural decision-making units (Munroe et al., 2007). Combining an agent-based and spatial regression techniques with other modelling method/techniques, therefore, can help solve spatial and temporal mismatch problems. 


\subsubsection{Cover of Multi-discipline and Multi Scale Approach}

Each method/technique works to a certain scale; combining two or more methods/techniques is the key to addressing the multi-spatiotemporal scale characteristics of land-use systems (Rindfuss et al., 2004; Verburg et al., 2004). Methodological integration helps link macro-level analysis with micro-level dynamics to cover multiple aspects of complex land systems, giving such models an advantage over traditional approaches (Erb et al., 2013; Lambin et al., 2006). Multi-scale analysis can be obtained by combining rule-based/SD models or economic models with one of the following models: Markov Chains, statistical models, CA and ANNs. SD and economic models are used for estimating land demand and considering driving forces (mostly macro-economic and demographic factors, as well as social, accessibility and climate variables) on a broad scale - typically at the level of administrative spatial units. Markov Chains, statistical models, CA and ANNs are used to explain land allocation, typically at a polygon or pixel micro level, and the underlying process that leads to different land-use patterns and change based on biophysical drivers such as soil type, water level and distance to roads. The integrated approach also supports models that operate on a global scale. There is a need for more land-use projections on this scale, especially with regard to climate change issues and environmental impact assessments of land-use change. Many important drivers and consequences of land-use change are global - international trade shifts, land requirements in different world regions, and competition for water resources (B. L. Turner, 2009).

Temporal complexity in land-use models can be dealt with through integration with SD models. This allows for accurate representation of rapid time changes (a day or a month, for example) in a land-use change system (Tews et al., 2006; Wang et al., 2012).

\subsection{Limitations of Methodological Integration in Land-use Change Models}

In theory, more complex models should perform better than simple ones. Although methodological integration allows more variables, space time patterns and social-biophysical processes included in models, potential drawbacks must be taken into account. The representation of sophisticated mechanisms, such as feedback loops and cross-scale interactions is a time-consuming task (Rotmans et al., 2001). Time is needed to amplify a huge amount of data and to find and become familiar with the knowledge required to cover the multidisciplinary characteristics of the land-use process. Higher level of integration requires more data. While many global datasets are now available, a data gap (inconsistent data collection and a lack of sharing frameworks) remains, particularly with regards to developing countries. The process of data integration can be particularly difficult when data sources, units of analysis, spatial extent and spatial-temporal time resolution do not coincide. Furthermore, the absence of a standard classification of land-tenure systems causes difficulty in combining data from different sources (Rotmans et al., 2001).

Methodological integration or combining different techniques requires a wide knowledge of appropriate tools. A lack of knowledge about observations and measurements and the possibilities of conflicting evidence may generate a subjective model biased towards the field in which the modeller works. Researchers from the social sciences may tend to add complexity to the social aspect of the model, while generalizing about its biophysical components. Researchers in the natural sciences may do the opposite. This causes the imbalance in representing the interactions of social, economic, environmental and institutional subsystems (Melillo et al., 2014). Here the question fuels the argument that small and transparent models may be superior to large, complicated models. More knowledge and information does not necessarily mean less uncertainty, and vice versa. The higher the level of integration, the more sources of uncertainty. To solve this issue, error propagation analysis is included in many recent models (Klein Goldewijk et al., 2013). 


\subsection{Future Trends of Methodological Integration in Land-use Change Models}

Our review has identified three main trends in the development of methodological integration. Firstly, it is the systematic feature (Briassoulis, 2000; Gharib, 2008; Hartt, 2011; Milne et al., 2009; Pfaffenbichler et al., 2010). Land-use change is a dynamic and non-linear process. In order to model and better understand non-linear dynamic systems, their main components and interactions must be described. The system approach examines land-use change as one component of a socio-ecological system. Once a system model has been constructed, 'what-if' scenarios can be explored more easily than is the case with non-system models (Agarwal et al., 2002). Systematic linking of socio-economic and biophysical drivers and trajectories is needed in order to better understand the thresholds of land use change. This is particularly crucial for assessing future scenarios and the relative impacts of different policy choices.

The second trend is broader boundaries in land-use change models as the method from different disciplines can be combined with each other (Barson et al., 2004; Salvati et al., 2013). Land is used interacts with climate change to affect human communities and ecosystems. At the same time, climate change directly affects where humans live and how they use land (Melillo et al., 2014). Calculating the land-atmosphere exchange in global climate models and predicting the impact of the climate on patterns of land-use are essential components of comprehensive models. In turn, the use of land is linked to options for reducing the speed and extent of climate change, such as expanding forests to accelerate removal of carbon from the atmosphere, modifying the way cities are built and organized to reduce energy and motor transport demands, or altering agricultural management practices to increase carbon storage in soil. In the field of energy safety, land-use models consider the problems associated with biofuels to ensure effective and sustainable land-use management (Diogo et al., 2014; Liu et al., 2012). It is essential such matters are considered if comprehensive integrated models are to cover short-term drivers of global land-use change, such as policy, and mid- and long-term drivers such as societies, economies, technologies and the climate.

Finally, methodological integration amplifies transparency within land-use change model. The development of models depends on knowledge from many disciplines: solutions that integrate knowledge from different land-use sectors are needed. By constructing models in a transparent and inclusive manner, decisions about model parameters are more easily justified to policy makers and the wider modelling community, even where such decisions do not lead to immediate technical improvements. Model output is best evaluated by model developers in cooperation with stakeholders, for this approach limits the chance of mistaken interpretations and conclusions. A land change model created through widespread participation can save later on time-consuming experimental work and calibration processes (Hewitt et al., 2014). And given the development of information technology, sharing data and knowledge is fast, cheap and convenient (Paolucci et al., 2012). Rapid developments in web mapping and the use of geographic information has given rise to neogeography, crowdsourcing and open sources, thereby offering science an unprecedented opportunity to extend its findings beyond the laboratory and refereed journals to the general public (Goodchild et al., 2012). In this regard, open modular platforms that combine software tools and economic assessment routines allow for stakeholder involvement (Fürst et al., 2013). A number of governments have embraced new technologies, including smartphone applications and online interfaces, to involve constituents in land-use planning (Goodchild et al., 2012). Crowdsourcing platforms help to visualize the results of land-use change models, and sometimes enclose the land-use modelling function within the platform environment itself, as is the case with Europe's FuturICT (Bishop et al., 2011). An even more advanced form of user intervention is offered by interactive models of land-use change, where the user interacts continuously with the model by modifying parameters, providing information (on preferences and priorities, for example), and choosing solutions that most closely match the problem under study (Briassoulis, 2000; Paolucci et al., 2012). The system integrates an agent-based model within an interactive visualization environment, provided through a web interface, to facilitate stakeholder learning in the study area (Pooyandeh et al., 2013). Relevant studies in this regard are Pokahr et al. (2007) and Pooyandeh et al (2013). Spatial 
web/agent-based models help to enhance decision making in land management, if the perspectives of stakeholders are considered. The participation approach is an increasingly important aspect of producing a fully integrated, calibrated and valid model (Hosseinali et al., 2013; Jiang et al., 2012; Kelley et al., 2011; Ligtenberg et al., 2004; Matthews et al., 2007; van Vliet et al., 2013).

\section{CONCLUSION}

This review has shown that there are many different combinations of modelling techniques. There is vast potential for researchers to develop models that make significant contributions to land-use change research and sustainable management policy.

Current methodological integration within land-use models highlight the extent of development in this field in recent years. Multi-scale analysis can overcome some of the intrinsic temporal and spatial deficits of the geographic, economic and system dynamic approaches. In particular, comprehensive integrated models take account of agent and stakeholder participation, which helps researchers to link scientific findings and political and social decisions.

It is important to remember, however, that the integration approach has drawbacks. The simultaneous incorporation of many factors into land-use change models is constrained by the quality and character of the assumptions and data. Increasing the level of functional and spatial aggregation may provide a better representation of these underlying processes, but this will come at the expense of computational efficiency and the ability of the user to interpret, comprehend and employ the model's results. Hence, there is a trade-off between the level of disaggregation and the ease with which results can be used.

While current integrated approaches have great potential, more work is required to improve the modelling of land-use dynamics. The new generation of integrated land-use models will benefit from having transparent structures that employ data quality assessment and reporting tools. Standard protocols need to be established to assess the accuracy of land-use and land-cover classifications. 


\section{REFERENCES}

Adhikari, S., \& Southworth, J. (2012). Simulating Forest Cover Changes of Bannerghatta National Park Based on a CA-Markov Model: A Remote Sensing Approach. Remote Sensing, 4(10), 3215-3243. doi:10.3390/rs4103215

Agarwal, C., Green, G. M., Grove, J. M., Evans, T. P., \& Schweik, C. M. (2002). A review and assessment of land-use change models: dynamics of space, time, and human choice. US Department of Agriculture Gen. Tech. Rep, NE-297.

Aisa, B., Mingus, B., \& O’Reilly, R. (2008). The Emergent neural modeling system. Neural Networks, 21(8), 1146-1152. doi:10.1016/j.neunet.2008.06.016

Almeida, C. M., Gleriani, J. M., Castejon, E. F., \& Soares-Filho, B. S. (2008). Using neural networks and cellular automata for modelling intra-urban land-use dynamics. International Journal of Geographical Information Science, 22(9), 943-963. doi:10.1080/13658810701731168

Barson, M. M., Randall, L. A., \& Barry, S. C. (2004). Modelling greenhouse gas emissions from land cover change: Linking continental data with point/patch models. Mathematics and Computers in Simulation, 64(3-4), 329-337. doi:10.1016/S0378-4754(03)00099-5

Berger, T. (2001). Agent-based spatial models applied to agriculture: A simulation tool for technology diffusion, resource use changes and policy analysis. Agricultural Economics, 25(2-3), 245-260. doi:10.1111/j.1574-0862.2001.tb00205.x

Bishop, S., Helbing, D., Lukowicz, P., \& Conte, R. (2011). FuturICT: FET Flagship Pilot Project. Procedia Computer Science, 7, 34-38. doi:10.1016/j.procs.2011.12.014

Breuer, L., Huisman, J. A., \& Frede, H. G. (2006). Monte Carlo assessment of uncertainty in the simulated hydrological response to land use change. Environmental Modeling and Assessment, 11(3), 209-218. doi:10.1007/ s10666-006-9051-9

Briassoulis, H. (2000). Analysis of Land Use Change: Theoretical and Modeling Approaches Retrieved from http://www.rri.wvu.edu/WebBook/Briassoulis/contents.htm

Britz, W., Verburg, P. H., \& Leip, A. (2011). Modelling of land cover and agricultural change in Europe: Combining the CLUE and CAPRI-Spat approaches. Agriculture, Ecosystems \& Environment, 142(1-2), 40-50. doi:10.1016/j.agee.2010.03.008

Brown, D. G., Riolo, R., Robinson, D. T., North, M., \& Rand, W. (2005). Spatial Process and Data Models: Toward Integration of Agent-Based Models and GIS. Journal of Geographical Systems, Special Issue on SpaceTime Information Systems. Journal of Geographical Systems, 7(1), 25-47. doi:10.1007/s10109-005-0148-5

Cai, M., \& Kalnay, E. (2004). Climate (communication arising): Impact of land-use change on climate. Nature, 427(6971), 214-214. doi:10.1038/427214a

Carneiro, T. G., Aguiar, A. P., Escada, M. I., Câmara, G., \& Antônio, M. M. (2004). Modelling Environment for non-isotropic and non-homogeneous spatial dynamic models development. Divisão de Processamento de Imagens, National Institute of Space Research - INPE São José dos Campos-SP, Brazil.

Castella, J.-C., \& Verburg, P. H. (2007). Combination of process-oriented and pattern-oriented models of land-use change in a mountain area of Vietnam. Ecological Modelling, 202(3-4), 410-420. doi:10.1016/j. ecolmodel.2006.11.011

Changhui, P., \& Xuezhi, W. (1999). Recent Applications of Artificial Neural Networks in Forest Resource Management: An Overview. AAAI Technical Report, WS-99-07.

Charif, O., Omrani, H., \& Basse, R.-M. (2012). Cellular automata based on artificial neural network for simulating land use changes. Paper presented at the Proceedings of the 45th Annual Simulation Symposium, Orlando, Florida (pp. 1-9).

Chaudhuri, G., \& Clarke, K. C. (2012). The SLEUTH Land Use Change Model: A Review. The International Journal of Environmental Resources Research, 1(1), 89. 
Chen, L., \& Nuo, W. (2013). Dynamic Simulation of Land Use Changes in Port City: A Case Study of Dalian, China. Procedia: Social and Behavioral Sciences, 96, 981-992. doi:10.1016/j.sbspro.2013.08.112

Chhabra, A., Geist, H., Houghton, R., Haberl, H., Braimoh, A., Vlek, P. G., \& Lambin, E. et al. (2006). Multiple Impacts of Land-Use/Cover Change. In E. Lambin \& H. Geist (Eds.), Land-Use and Land-Cover Change (pp. 71-116). Springer Berlin Heidelberg. doi:10.1007/3-540-32202-7_4

Clarke, K. (2008). Mapping and Modelling Land Use Change: an Application of the SLEUTH Model. In C. Pettit, W. Cartwright, I. Bishop, K. Lowell, D. Pullar \& D. Duncan (Eds.), Landscape Analysis and Visualisation (pp. 353-366): Springer Berlin Heidelberg. doi:10.1007/978-3-540-69168-6_17

Clarke, K. C., \& Gaydos, L. J. (1998). Loose-coupling a cellular automaton model and GIS: Long-term urban growth prediction for San Francisco and Washington/Baltimore. International Journal of Geographical Information Science, 12(7), 699-714. doi:10.1080/136588198241617

Costanza, R., Sklar, F. H., \& White, M. L. (1990). Modelling coastal landscape dynamics. Process-based dynamic ecosystem simulation can examine long-term natural changes and human impacts. Bioscience, 40(2), 91-107. doi: $10.2307 / 1311342$

Costanza, R., Wainger, L., Folke, C., \& Maler, K.-G. (1993). Modeling Complex Ecological Economic Systems. Bioscience, 43(8), 545-555. doi:10.2307/1311949

da C Jesus, E., Marsh, T. L., Tiedje, J. M., \& de S Moreira, F. M.da C Jesus. (2009). Changes in land use alter the structure of bacterial communities in Western Amazon soils. The ISME Journal, 3(9), 1004-1011. doi:10.1038/ ismej.2009.47

de Nijs, T. C. M., de Niet, R., \& Crommentuijn, L. (2004). Constructing land-use maps of the Netherlands in 2030. Journal of Environmental Management, 72(1-2), 35-42. doi:10.1016/j.jenvman.2004.03.015

Deal, B., \& Schunk, D. (2004). Spatial dynamic modeling and urban land use transformation: A simulation approach to assessing the costs of urban sprawl. Ecological Economics, 51(1-2), 79-95. doi:10.1016/j. ecolecon.2004.04.008

Ding, W. J., Wang, R. Q., Wu, D. Q., \& Liu, J. (2013). Cellular automata model as an intuitive approach to simulate complex land-use changes: An evaluation of two multi-state land-use models in the Yellow River Delta. Stochastic Environmental Research and Risk Assessment, 27(4), 899-907. doi:10.1007/s00477-012-0624-7

Diogo, V., van der Hilst, F., van Eijck, J., Verstegen, J. A., Hilbert, J., Carballo, S., \& Faaij, A. et al. (2014). Combining empirical and theory-based land-use modelling approaches to assess economic potential of biofuel production avoiding iLUC: Argentina as a case study. Renewable \& Sustainable Energy Reviews, 34(0), $208-224$. doi:10.1016/j.rser.2014.02.040

Donella, H. M., Dennis, L. M., Jorgen, R., \& Williams, W. B. I. (1972). The Limits to Growth NewYork. Universe Books.

Eeftens, M., Beelen, R., de Hoogh, K., Bellander, T., Cesaroni, G., Cirach, M., \& Hoek, G. et al. (2012). Development of Land Use Regression Models for PM2.5, PM2.5 Absorbance, PM10 and PMcoarse in 20 European Study Areas; Results of the ESCAPE Project. Environmental Science \& Technology, 46(20), 11195-11205. doi:10.1021/es301948k

Erb, K. H., Haberl, H., Jepsen, M. R., Kuemmerle, T., Lindner, M., Müller, D., \& Reenberg, A. et al. (2013). A conceptual framework for analysing and measuring land-use intensity. Current Opinion in Environmental Sustainability, 5(5), 464-470. doi:10.1016/j.cosust.2013.07.010

Eric, K., John, S., \& Aldrik, B. (2007). Henk j., S (Vol. 90). Modelling Land-Use Change Progress and Applications.

Evans, T. P., \& Kelley, H. (2004). Multi-scale analysis of a household level agent-based model of landcover change. Journal of Environmental Management, 72(1-2), 57-72. doi:10.1016/j.jenvman.2004.02.008

Fan, F., Wang, Y., \& Wang, Z. (2008). Temporal and spatial change detecting (1998-2003) and predicting of land use and land cover in Core corridor of Pearl River Delta (China) by using TM and ETM+ images. Environmental Monitoring and Assessment, 137(1-3), 127-147. doi:10.1007/s10661-007-9734-y 
Fennell, L. A. (2013). Crowdsourcing Land Use. Brooklyn Law Review, 78, 32.

Filatova, T., Verburg, P. H., Parker, D. C., \& Stannard, C. A. (2013). Spatial agent-based models for socioecological systems: Challenges and prospects. Environmental Modelling \& Software, 45(0), 1-7. doi:10.1016/j. envsoft.2013.03.017

Freier, K. P., Schneider, U. A., \& Finckh, M. (2011). Dynamic interactions between vegetation and land use in semi-arid Morocco: Using a Markov process for modeling rangelands under climate change. Agriculture, Ecosystems \& Environment, 140(3-4), 462-472. doi:10.1016/j.agee.2011.01.011

Fu, L. (1995). Introduction to knowledge-based neural networks. Knowledge-Based Systems, 8(6), 299-300. doi:10.1016/0950-7051(96)81914-9

Fürst, C., Helming, K., Lorz, C., Müller, F., \& Verburg, P. H. (2013). Integrated land use and regional resource management - A cross-disciplinary dialogue on future perspectives for a sustainable development of regional resources. Journal of Environmental Management, 127, S1-S5.

Geertman, S., Hagoort, M., \& Ottens, H. (2007). Spatial-temporal specific neighbourhood rules for cellular automata land use modelling. International Journal of Geographical Information Science, 21(5), 547-568. doi:10.1080/13658810601064892

Ghaffarzadegan, N., Lyneis, J., \& Richardson, G. P. (2011). How small system dynamics models can help the public policy process. System Dynamics Review, 27(1), 22-44.

Gharib, S. (2008). Synthesizing system dynamics and geographic information systems in a new method to model and simulate environmental systems. University of Bergen, Norway.

Gibreel, T. M., Herrmann, S., Berkhoff, K., Nuppenau, E.-A., \& Rinn, A. (2014). Farm types as an interface between an agroeconomical model and CLUE-Naban land change model: Application for scenario modelling. Ecological Indicators, 36(0), 766-778. doi:10.1016/j.ecolind.2013.09.009

Global Land Project. (2005a). Annual report. IGBP Report No. 53/IHDP Report No. 19.IGBP Secretariat, Stockholm.64.

Global Land Project. (2005b). Science Plan and Implementation Strategy. IGBP Report No. 53/IHDP Report No. 19.64 .

Goodchild, M. F., Guo, H., Annoni, A., Bian, L., de Bie, K., Campbell, F., \& Woodgate, P. et al. (2012). Nextgeneration Digital Earth. Proceedings of the National Academy of Sciences.

Guan, D., Li, H., Inohae, T., Su, W., Nagaie, T., \& Hokao, K. (2011). Modeling urban land use change by the integration of cellular automaton and Markov model. Ecological Modelling, 222(20-22), 3761-3772. doi:10.1016/j.ecolmodel.2011.09.009

Han, J., Hayashi, Y., Cao, X., \& Imura, H. (2009). Application of an integrated system dynamics and cellular automata model for urban growth assessment: A case study of Shanghai, China. Landscape and Urban Planning, 91(3), 133-141. doi:10.1016/j.landurbplan.2008.12.002

Hartt, M. D. (2011). Geographic information systems and system dynamics - modelling the impacts of storm damage on coastal communities. University of Ottawa.

He, C., Shi, P., Chen, J., Li, X., Pan, Y., Li, J., \& Li, J. et al. (2005). Developing land use scenario dynamics model by the integration of system dynamics model and cellular automata model. Science in China Series D: Earth Sciences, 48(11), 1979-1989. doi:10.1360/04yd0248

Heistermann, M., Müller, C., \& Ronneberger, K. (2006). Land in sight?: Achievements, deficits and potentials of continental to global scale land-use modeling. Agriculture, Ecosystems \& Environment, 114(2-4), 141-158. doi:10.1016/j.agee.2005.11.015

Helming, K., Diehl, K., Bach, H., Dilly, O., König, B., Kuhlman, T., \& Wiggering, H. et al. (2011). Ex Ante Impact Assessment of Policies Affecting Land Use, Part A: Analytical Framework. Ecology and Society, 16(1).

Herold, M., Goldstein, N. C., \& Clarke, K. C. (2003). The spatiotemporal form of urban growth: Measurement, analysis and modeling. Remote Sensing of Environment, 86(3), 286-302. doi:10.1016/S0034-4257(03)00075-0 
Hertel, T. W. (1997). Global Trade Analysis: Modeling and Applications. Cambridge, UK: Cambridge University Press.

Hewitt, R., van Delden, H., \& Escobar, F. (2014). Participatory land use modelling, pathways to an integrated approach. Environmental Modelling \& Software, 52, 149-165. doi:10.1016/j.envsoft.2013.10.019

Hilferink, M., \& Rietveld, P. (1999). Land use scanner: An integrated GIS based model for long term projections of land use in urban and rural areas. Journal of Geographical Systems, 1(2), 155-177. doi:10.1007/s101090050010

Hof, C., Araujo, M. B., Jetz, W., \& Rahbek, C. (2011). Additive threats from pathogens, climate and land-use change for global amphibian diversity. Nature, 480(7378), 516-519.

Hosseinali, F., Alesheikh, A. A., \& Nourian, F. (2013). Agent-based modeling of urban land-use development, case study: Simulating future scenarios of Qazvin city. Cities (London, England), 31, 105-113. doi:10.1016/j. cities.2012.09.002

Houet, T., \& Hubert-Moy, L. (2006). Modelling and projecting land-use and land-cover changes with a Cellular Automaton in considering landscape trajectories: An improvement for simulation of plausible future states. EARSeL eProceedings, 5(1), 63-76.

Hu, Z., \& Lo, C. P. (2007). Modeling urban growth in Atlanta using logistic regression. Computers, Environment and Urban Systems, 31(6), 667-688. doi:10.1016/j.compenvurbsys.2006.11.001

Irwin, E. G., \& Geoghegan, J. (2001). Theory, data, methods: Developing spatially explicit economic models of land use change. Agriculture, Ecosystems \& Environment, 85(1-3), 7-24. doi:10.1016/S0167-8809(01)00200-6

Jantz, C. A., \& Goetz, S. J. (2005). Analysis of scale dependencies in an urban land-use-change model. International Journal of Geographical Information Science, 19(2), 217-241. doi:10.1080/136588104100017 13425

Jenerette, G. D., \& Wu, J. (2001). Analysis and simulation of land-use change in the central Arizona - Phoenix region, USA. Landscape Ecology, 16(7), 611-626. doi:10.1023/A:1013170528551

Jiang, L., Deng, X., \& Seto, K. C. (2012). Multi-level modeling of urban expansion and cultivated land conversion for urban hotspot counties in China. Landscape and Urban Planning, 108(2-4), 131-139. doi:10.1016/j. landurbplan.2012.08.008

Jokar Arsanjani, J., Helbich, M., Kainz, W., \& Darvishi Boloorani, A. (2013). Integration of logistic regression, Markov chain and cellular automata models to simulate urban expansion. International Journal of Applied Earth Observation and Geoinformation, 21, 265-275. doi:10.1016/j.jag.2011.12.014

Kamusoko, C., Aniya, M., Adi, B., \& Manjoro, M. (2009). Rural sustainability under threat in Zimbabwe Simulation of future land use/cover changes in the Bindura district based on the Markov-cellular automata model. Applied Geography (Sevenoaks, England), 29(3), 435-447. doi:10.1016/j.apgeog.2008.10.002

Kelley, H., \& Evans, T. (2011). The relative influences of land-owner and landscape heterogeneity in an agentbased model of land-use. Ecological Economics, 70(6), 1075-1087. doi:10.1016/j.ecolecon.2010.12.009

Kityuttachai, K., Tripathi, N., Tipdecho, T., \& Shrestha, R. (2013). CA-Markov Analysis of Constrained Coastal Urban Growth Modeling: Hua Hin Seaside City, Thailand. Sustainability, 5(4), 1480-1500. doi:10.3390/ su5041480

Klein Goldewijk, K., \& Verburg, P. (2013). Uncertainties in global-scale reconstructions of historical land use: An illustration using the HYDE data set. Landscape Ecology, 28(5), 861-877. doi:10.1007/s10980-013-9877-x

Lagarias, A. (2012). Urban sprawl simulation linking macro-scale processes to micro-dynamics through cellular automata, an application in Thessaloniki, Greece. Applied Geography (Sevenoaks, England), 34, 146-160. doi:10.1016/j.apgeog.2011.10.018

Lambin, E. F. (1994). Modelling Deforestation Processes. A review. Trees Series B Report n॰ 1. International Journal of Remote Sensing, 17(5), 1061-1062.

Lambin, E. F., \& Geist, H. J. (2006). Land-Use and Land-Cover Change: Local process and global impacts. Springer Berlin Heidelberg. doi:10.1007/3-540-32202-7 
Lambin, E. F., Geist, H. J., \& Lepers, E. (2003). Dynamics of land-use and land-cover change in tropical regions. Annual Review of Environment and Resources, 28(1), 205-241. doi:10.1146/annurev.energy.28.050302.105459

Lantman, J. V. S., Verburg, P. H., Bregt, A., \& Geertman, S. (2011). Core Principles and Concepts in Land-Use Modelling: A Literature Review. In E. Koomen \& J. Borsboom-van Beurden (Eds.), Land-Use Modelling in Planning Practice (Vol. 101, pp. 35-57). Springer Netherlands. doi:10.1007/978-94-007-1822-7_3

Lauf, S., Haase, D., Hostert, P., Lakes, T., \& Kleinschmit, B. (2012). Uncovering land-use dynamics driven by human decision-making - A combined model approach using cellular automata and system dynamics. Environmental Modelling \& Software, 27-28(0), 71-82. doi:10.1016/j.envsoft.2011.09.005

Le Page, C., Bousquet, C., Bakam, I., Bah, A., \& Baron, C. (2000). CORMAS: A multiagent simulation toolkit to model natural and social dynamics at multiple scales. Paper presented at the Wagenigen: Workshop 'The ecology of scales', Wagenigen, Netherlands.

Lee, S. T., Wu, C. W., \& Lei, T. C. (2013). CA-GIS Model for Dynamic Simulation of Commercial Activity Development by the Combination of ANN and Bayesian Probability. Procedia Computer Science, 18(0), 651-660. doi:10.1016/j.procs.2013.05.229

Lei, S., Zhu, J., Shaohong, R., Yuanman, H., \& Miao, L. (2012). Landscape Pattern Change Prediction Of Jinhu Coastal Area Based On Logistic-CA-Markov Model. Advances in information Sciences and Service Sciences(AISS), 4(11).

Lesschen, J. P., Verburg, P. H., \& Staal, S. J. (2005). Statistical methods for analysing the spatial dimension of changes in land use and farming systems. LUCC Report Series, 7.

Letourneau, A., Verburg, P. H., \& Stehfest, E. (2012). A land-use systems approach to represent land-use dynamics at continental and global scales. Environmental Modelling \& Software, 33, 61-79. doi:10.1016/j. envsoft.2012.01.007

Li, X., \& Yeh, A. G. O. (2000). Modelling sustainable urban development by the integration of constrained cellular automata and GIS. International Journal of Geographical Information Science, 14(2), 131-152. doi:10.1080/136588100240886

Li, X., \& Yeh, A. G. O. (2002). Neural-network-based cellular automata for simulating multiple land use changes using GIS. International Journal of Geographical Information Science, 16(4), 323-343. doi:10.1080/13658810210137004

Ligtenberg, A., Wachowicz, M., Bregt, A. K., Beulens, A., \& Kettenis, D. L. (2004). A design and application of a multi-agent system for simulation of multi-actor spatial planning. Journal of Environmental Management, 72(1-2), 43-55. doi:10.1016/j.jenvman.2004.02.007

Liu, J., \& Zheng, X. (2012). A Spatial-EF and Econometrics Model Integrated Approach to Explore Land Use Sustainable Forecast Model-in Case of Shandong Province. Procedia Environmental Sciences, 12(Part A), 413-420.

Liu, X., Ou, J., Li, X., \& Ai, B. (2013). Combining system dynamics and hybrid particle swarm optimization for land use allocation. Ecological Modelling, 257, 11-24. doi:10.1016/j.ecolmodel.2013.02.027

Lourdes, L., Karina, Z., Pedro, L., Héctor, M., \& Néstor, M. (2011). A dynamic simulation model of land cover in the Dulce Creek Basin, Argentina. Procedia Environmental Sciences, 7, 194-199. doi:10.1016/j. proenv.2011.07.034

Luo, D., \& Zhang, W. (2014). A comparison of Markov model-based methods for predicting the ecosystem service value of land use in Wuhan, central China. Ecosystem Services, 7, 57-65. doi:10.1016/j.ecoser.2013.11.001

Luo, G., Yin, C., Chen, X., Xu, W., \& Lu, L. (2010). Combining system dynamic model and CLUE-S model to improve land use scenario analyses at regional scale: A case study of Sangong watershed in Xinjiang, China. Ecological Complexity, 7(2), 198-207. doi:10.1016/j.ecocom.2010.02.001

Ma, C., Zhang, G. Y., Zhang, X. C., Zhao, Y. J., \& Li, H. Y. (2012). Application of Markov model in wetland change dynamics in Tianjin Coastal Area, China. Procedia Environmental Sciences, 13, 252-262. doi:10.1016/j. proenv.2012.01.024 
Maria de Almeida, C., Batty, M., Vieira Monteiro, A., Câmara, G., Soares-Filho, B., Cerqueira, G., \& Pennachin, C. (2003). Stochastic cellular automata modeling of urban land use dynamics: Empirical development and estimation. Computers, Environment and Urban Systems, 27(5), 481-509. doi:10.1016/S0198-9715(02)00042-X

Mas, J. F., Kolb, M., Paegelow, M., Camacho Olmedo, M. T., \& Houet, T. (2014). Inductive pattern-based land use/cover change models: A comparison of four software packages. Environmental Modelling \& Software, 51(0), 94-111. doi:10.1016/j.envsoft.2013.09.010

Matthews, R., Gilbert, N., Roach, A., Polhill, J. G., \& Gotts, N. (2007). Agent-based land-use models: A review of applications. Landscape Ecology, 22(10), 1447-1459. doi:10.1007/s10980-007-9135-1

Melillo, J. M., Terese, T. C. R., \& Yohe, G. W. (2014). Cimate Change Impacts in the United States: The Third National Climate Assessment. U.S. Global Change Research Program.841.

Michetti, M. (2012). Modelling Land Use, Land-Use Change, and Forestry in Climate Change: A Review of Major Approaches. FEEM Working Paper No. 46.2012; CMCC Research Paper No. 133.

Millennium Ecosystem Assessment. (2005). Ecosystems and Human Well-Being: Current State and Trends. London.

Milne, E., Aspinall, R., \& Veldkamp, T. (2009). Integrated modelling of natural and social systems in land change science. Landscape Ecology, 24(9), 1145-1147. doi:10.1007/s10980-009-9392-2

Mitsova, D., Shuster, W., \& Wang, X. (2011). A cellular automata model of land cover change to integrate urban growth with open space conservation. Landscape and Urban Planning, 99(2), 141-153. doi:10.1016/j. landurbplan.2010.10.001

Moreno, N., Wang, F., \& Marceau, D. J. (2009). Implementation of a dynamic neighborhood in a land-use vector-based cellular automata model. Computers, Environment and Urban Systems, 33(1), 44-54. doi:10.1016/j. compenvurbsys.2008.09.008

Müller, D. (2003). Land-use change in the Central Highlands of Vietnam: A spatial econometric model combining satellite imagery and village survey data. (Doctoral thesis), Georg-August University of Göttingen. Retrieved from http://ediss.uni-goettingen.de/handle/11858/00-1735-0000-0006-AB5C-0

Muller, M., \& Middleton, J. (1994). A Markov model of land-use change dynamics in the Niagara Region, Ontario, Canada. Landscape Ecology, 9(2), 151-157.

Munroe, D., \& Muller, D. (2007). Issues in spatially explicit statistical land-use/cover change (LUCC) models: Examples from western Honduras and the Central Highlands of Vietnam. Land Use Policy, 24(3), 521-530. doi:10.1016/j.landusepol.2005.09.007

Munthali, K. G., \& Murayama, Y. (2011). Land use/cover change detection and analysis for Dzalanyama forest reserve, Lilongwe, Malawi. Procedia: Social and Behavioral Sciences, 21, 203-211. doi:10.1016/j. sbspro.2011.07.035

Paegelow, M., Camacho, M., Ferraty, F., Ferré, L., Sarda, P., \& Villa, N. (2008). Prospective modelling of environmental dynamics: A methodological comparison applied to mountain land cover changes. In M. Paegelow \& M. Olmedo (Eds.), Modelling Environmental Dynamics (pp. 141-167). Springer Berlin Heidelberg. doi:10.1007/978-3-540-68498-5_5

Paolucci, M., Kossman, D., Conte, R., Lukowicz, P., Argyrakis, P., Blandford, A., \& Helbing, D. et al. (2012). Towards a living earth simulator. The European Physical Journal. Special Topics, 214(1), 77-108. doi:10.1140/ epjst/e2012-01689-8

Parker, D. C., Berger, T., Manson, S. M., \& McConnell, W. J. (2001) Agent-Based Models of Land-Use and Land-Cover Change. LUCC Report Series No. 6, Irvine, California, USA.

Parker, D. C., Manson, S. M., Janssen, M. A., Hoffmann, M. J., \& Deadman, P. (2003). Multi-Agent Systems for the Simulation of Land-Use and Land-Cover Change: A Review. Annals of the Association of American Geographers, 93(2), 314-337. doi:10.1111/1467-8306.9302004 
Perez, L., \& Dragicevic, S. (2012). Landscape-level simulation of forest insect disturbance: Coupling swarm intelligent agents with GIS-based cellular automata model. Ecological Modelling, 231(0), 53-64. doi:10.1016/j. ecolmodel.2012.01.020

Peterson, L. K., Bergen, K. M., Brown, D. G., Vashchuk, L., \& Blam, Y. (2009). Forested land-cover patterns and trends over changing forest management eras in the Siberian Baikal region. Forest Ecology and Management, 257(3), 911-922. doi:10.1016/j.foreco.2008.10.037

Pfaffenbichler, P., Emberger, G., \& Shepherd, S. (2010). A system dynamics approach to land use transport interaction modelling: The strategic model MARS and its application. System Dynamics Review, 26(3), 262-282. doi:10.1002/sdr.451

Pielke, R. A. Sr. (2005). Land Use and Climate Change. Science, 310(5754), 1625-1626. doi:10.1126/ science. 1120529

Pijanowski, B. C., Brown, D. G., Shellito, B. A., \& Manik, G. A. (2002). Using neural networks and GIS to forecast land use changes: A Land Transformation Model. Computers, Environment and Urban Systems, 26(6), 553-575. doi:10.1016/S0198-9715(01)00015-1

Pijanowski, B. C., Pithadia, S., Shellito, B. A., \& Alexandridis, K. (2005). Calibrating a neural network-based urban change model for two metropolitan areas of the Upper Midwest of the United States. International Journal of Geographical Information Science, 19(2), 197-215. doi:10.1080/13658810410001713416

Pinto, N. N., \& Antunes, A. P. (2007). Cellular automata and urban studies: A literature survey. Architecture. City and Environment, 4, 471-486.

Pokahr, A., \& Braubach, L. (2007). An Architecture and Framework for Agent-Based Web Applications. In H.D. Burkhard, G. Lindemann, R. Verbrugge, \& L. Varga (Eds.), Multi-Agent Systems and Applications V, LNCS (Vol. 4696, pp. 304-306). Springer Berlin Heidelberg. doi:10.1007/978-3-540-75254-7_32

Pontius, G. R., \& Malanson, J. (2005). Comparison of the structure and accuracy of two land change models. International Journal of Geographical Information Science, 19(2), 243-265. doi:10.1080/136588104100017 13434

Pontius, R. G. Jr, \& Schneider, L. C. (2001). Land-cover change model validation by an ROC method for the Ipswich watershed, Massachusetts, USA. Agriculture, Ecosystems \& Environment, 85(1-3), 239-248. doi:10.1016/ S0167-8809(01)00187-6

Pooyandeh, M., \& Marceau, D. J. (2013). A spatial web/agent-based model to support stakeholders' negotiation regarding land development. Journal of Environmental Management, 129(0), 309-323. doi:10.1016/j. jenvman.2013.07.028

Poska, A., Sepp, E., Veski, S., \& Koppel, K. (2008). Using quantitative pollen-based land-cover estimations and a spatial CA_Markov model to reconstruct the development of cultural landscape at Rõuge, South Estonia. Vegetation History and Archaeobotany, 17(5), 527-541. doi:10.1007/s00334-007-0124-8

Reidsma, P., König, H., Feng, S., Bezlepkina, I., Nesheim, I., Bonin, M., \& Brouwer, F. et al. (2011). Methods and tools for integrated assessment of land use policies on sustainable development in developing countries. Land Use Policy, 28(3), 604-617. doi:10.1016/j.landusepol.2010.11.009

Rindfuss, R. R., Walsh, S. J., Turner, B. L., Fox, J., \& Mishra, V. (2004). Developing a science of land change: Challenges and methodological issues. Proceedings of the National Academy of Sciences of the United States of America, 101(39), 13976-13981. doi:10.1073/pnas.0401545101

Roetter, R. P., Hoanh, C. T., Laborte, A. G., Van Keulen, H., Van Ittersum, M. K., Dreiser, C., \& Van Laar, H. H. et al. (2005). Integration of Systems Network (SysNet) tools for regional land use scenario analysis in Asia. Environmental Modelling \& Software, 20(3), 291-307. doi:10.1016/j.envsoft.2004.01.001

Ronneberger, K., Maria, B., Francesco, B., \& Richard, T. (2009). KLUM@GTAP: Spatially explicit, biophysical land use in a computable general equilibrium model. In T. W. Hertel, S. K. Rose, \& R. S. J. Tol (Eds.), Economic Analysis of Land Use in Global Climate Change Policy (pp. 304-338). New York: Routledge. 
Rosenblatt, F. (1958). The perceptron: A probabilistic model for information storage and organization in the brain. Psychological Review, 65(6), 386-408. doi:10.1037/h0042519

Rotmans, J., \& van Asselt, M. A. (2001). Uncertainty Management in Integrated Assessment Modeling: Towards a Pluralistic Approach. Environmental Monitoring and Assessment, 69(2), 101-130. doi:10.1023/A:1010722120729

Rounsevell, M. D. A., Pedroli, B., Erb, K. H., Gramberger, M., Busck, A. G., Haberl, H., \& Wolfslehner, B. et al. (2012). Challenges for land system science. Land Use Policy, 29(4), 899-910. doi:10.1016/j. landusepol.2012.01.007

Rutten, M., van Dijk, M., van Rooij, W., \& Hilderink, H. (2014). Land Use Dynamics, Climate Change, and Food Security in Vietnam: A Global-to-local Modeling Approach. World Development, 59(0), 29-46. doi:10.1016/j. worlddev.2014.01.020

Salvati, L., Sateriano, A., \& Zitti, M. (2013). Long-term land cover changes and climate variations - A countryscale approach for a new policy target. Land Use Policy, 30(1), 401-407. doi:10.1016/j.landusepol.2012.04.012

Sang, L., Zhang, C., Yang, J., Zhu, D., \& Yun, W. (2011). Simulation of land use spatial pattern of towns and villages based on CA-Markov model. Mathematical and Computer Modelling, 54(3-4), 938-943. doi:10.1016/j. mcm.2010.11.019

Schaldach, R., Alcamo, J., Koch, J., Kölking, C., Lapola, D. M., Schüngel, J., \& Priess, J. A. (2011). An integrated approach to modelling land-use change on continental and global scales. Environmental Modelling \& Software, 26(8), 1041-1051. doi:10.1016/j.envsoft.2011.02.013

Schneider, S. (1997). Integrated assessment modeling of global climate change: Transparent rational tool for policy making or opaque screen hiding value-laden assumptions? Environmental Modeling and Assessment, 2(4), 229-249. doi:10.1023/A:1019090117643

Seto, K. C., Güneralp, B., \& Hutyra, L. R. (2012). Global forecasts of urban expansion to 2030 and direct impacts on biodiversity and carbon pools. Proceedings of the National Academy of Sciences of the United States of America, 109(40), 16083-16088. doi:10.1073/pnas.1211658109

Shen, Q., Chen, Q., Tang, B.-, Yeung, S., Hu, Y., \& Cheung, G. (2009). A system dynamics model for the sustainable land use planning and development. Habitat International, 33(1), 15-25. doi:10.1016/j. habitatint.2008.02.004

Shen, T. Y., Wang, W. D., Hou, M., Guo, Z. C., Xue, L., \& Yang, K. Z. (2007). Study on Spatio-Temporal System Dynamic Models of Urban Growth. Systems Engineering - Theory \& Practice, 27(1), 10-17.

Silva, E. A., Ahern, J., \& Wileden, J. (2008). Strategies for landscape ecology: An application using cellular automata models. Progress in Planning, 70(4), 133-177. doi:10.1016/j.progress.2008.05.002

Sohl, T., \& Sayler, K. (2008). Using the FORE-SCE model to project land-cover change in the southeastern United States. Ecological Modelling, 219(1-2), 49-65. doi:10.1016/j.ecolmodel.2008.08.003

Steffen, W., Sanderson, R. A., Tyson, P. D., Jäger, J., Matson, P. A., Moore III, B., Oldfield, F., Richardson, K., Schellnhuber, H.-J., Turner, B. L., \& Wasson, R. J. (2005). Global Change and the Earth System A Planet Under Pressure.

N. Stephenne, e. F. L. (2001). Backward Land-Cover Change Projections for the Sudano- Sahelian Countries of Africa with a Dynamic Simulation Model of Land-Use Change (SALU).

Stéphenne, N., \& Lambin, E. F. (2001). A dynamic simulation model of land-use changes in Sudano-sahelian countries of Africa (SALU). Agriculture, Ecosystems \& Environment, 85(1-3), 145-161. doi:10.1016/S01678809(01)00181-5

Sterling, S., Ducharne, A., \& Polcher, J. (2012). The impact of global land-cover change on the terrestrial water cycle. Nature Climate Change, advance online publication.

Stevens, D., \& Dragicevic, S. (2007). A GIS-based irregular cellular automata model of land-use change. Environment and Planning. B, Planning \& Design, 34(4), 708-724. doi:10.1068/b32098 
Strengers, B., Leemans, R., Eickhout, B., Vries, B., \& Bouwman, L. (2004). The land-use projections and resulting emissions in the IPCC SRES scenarios scenarios as simulated by the IMAGE 2.2 model. GeoJournal, 61(4), 381-393. doi:10.1007/s10708-004-5054-8

Subedi, P., Subedi, K., \& Thapa, B. (2013). Application of a Hybrid Cellular Automaton "C Markov (CA-Markov) Model in Land-Use Change Prediction: A Case Study of Saddle Creek Drainage Basin, Florida. Applied Ecology and Environmental Sciences, 1(6), 126-132. doi:10.12691/aees-1-6-5

Sui, D. Z., \& Zeng, H. (2001). Modeling the dynamics of landscape structure in Asia's emerging desakota regions: A case study in Shenzhen. Landscape and Urban Planning, 53(1-4), 37-52. doi:10.1016/S0169-2046(00)00136-5

Sun, H., Forsythe, W., \& Waters, N. (2007). Modeling Urban Land Use Change and Urban Sprawl: Calgary, Alberta, Canada. Networks and Spatial Economics, 7(4), 353-376. doi:10.1007/s11067-007-9030-y

Swartz, C. H., Rudel, R. A., Kachajian, J. R., \& Brody, J. G. (2003). Historical reconstruction of wastewater and land use impacts to groundwater used for public drinking water: Exposure assessment using chemical data and GIS. Journal of Exposure Analysis and Environmental Epidemiology, 13(5), 403-416. doi:10.1038/sj.jea.7500291

Takamatsu, M., Kawasaki, A., Rogers, P., \& Malakie, J. (2014). Development of a land-use forecast tool for future water resources assessment: Case study for the Mekong River 3S Sub-basins. Sustainability Science, 9(2), 157-172. doi:10.1007/s11625-013-0225-5

Tayyebi, A., Pijanowski, B. C., \& Tayyebi, A. H. (2011). An urban growth boundary model using neural networks, GIS and radial parameterization: An application to Tehran, Iran. Landscape and Urban Planning, 100(1-2), 35-44. doi:10.1016/j.landurbplan.2010.10.007

Tews, J., Esther, A., Milton, S. J., \& Jeltsch, F. (2006). Linking a population model with an ecosystem model: Assessing the impact of land use and climate change on savanna shrub cover dynamics. Ecological Modelling, 195(3-4), 219-228. doi:10.1016/j.ecolmodel.2005.11.025

Thapa, R. B., \& Murayama, Y. (2011). Urban growth modeling of Kathmandu metropolitan region, Nepal. Computers, Environment and Urban Systems, 35(1), 25-34. doi:10.1016/j.compenvurbsys.2010.07.005

Tobler, W. (1979). Cellular geography. In S. Gale \& G. Olsson (Eds.). Philosophy in geography, 379-386. doi:10.1007/978-94-009-9394-5_18

Turner, B.L., Meyer, W.B., \& Skole, D.L. (2009). Global Land-Use/Land-Cover Change: Towards an Integrated Study. Ambio, 23(1), 91-95.

Turner, B. L., Skole, D., Sanderson, S., Fischer, G., Fresco, L., \& Leemans, R. (1999). Land-Use and Land-Cover Change; Science/Research Plan. HDP Report No.7. Stockholm and Geneva.

Valbuena, D. F., Verburg, P. H., Bregt, A. K., \& Ligtenberg, A. (2010). An agent-based approach to model landuse change at a regional scale. Landscape Ecology, 25(2), 185-199. doi:10.1007/s10980-009-9380-6

Van Duivenbooden, N., Bitchibaly, K., \& Tiendrebeogo, J. P. (1998). Multi-scale land use systems analysis: A bridge between researchers and stakeholders: An example for semi-arid West Africa. The Land, 2(3), 155-171.

van Meijl, H., van Rheenen, T., Tabeau, A., \& Eickhout, B. (2006). The impact of different policy environments on agricultural land use in Europe. Agriculture, Ecosystems \& Environment, 114(1), 21-38. doi:10.1016/j. agee.2005.11.006

Van Paassen, A., Roetter, R. P., Van Keulen, H., \& Hoanh, C. T. (2007). Can computer models stimulate learning about sustainable land use? Experience with LUPAS in the humid (sub-)tropics of Asia. Agricultural Systems, 94(3), 874-887. doi:10.1016/j.agsy.2006.11.012

van Vliet, J., Naus, N., van Lammeren, R. J. A., Bregt, A. K., Hurkens, J., \& van Delden, H. (2013). Measuring the neighbourhood effect to calibrate land use models. Computers, Environment and Urban Systems, 41, 55-64. doi:10.1016/j.compenvurbsys.2013.03.006

Veldkamp, A., \& Fresco, L. O. (1996). CLUE-CR: An integrated multi-scale model to simulate land use change scenarios in Costa Rica. Ecological Modelling, 91(1-3), 231-248. doi:10.1016/0304-3800(95)00158-1 
Veldkamp, A., \& Lambin, E. F. (2001). Predicting land-use change. Agriculture, Ecosystems \& Environment, 85(1-3), 1-6. doi:10.1016/S0167-8809(01)00199-2

Verburg, P., Eickhout, B., \& Meijl, H. (2008). A multi-scale, multi-model approach for analyzing the future dynamics of European land use. The Annals of Regional Science, 42(1), 57-77. doi:10.1007/s00168-007-0136-4

Verburg, P., Schot, P., Dijst, M., \& Veldkamp, A. (2004). Land use change modelling: Current practice and research priorities. GeoJournal, 61(4), 309-324. doi:10.1007/s10708-004-4946-y

Verburg, P. H., Groot, W. T., \& Veldkamp, A. J. (2003). Methodology for Multi-Scale Land-Use Change Modelling: Concepts and Challenges. In A. J. Dolman, A. Verhagen, \& C. A. Rovers (Eds.), Global Environmental Change and Land Use (pp. 17-51). Springer Netherlands. doi:10.1007/978-94-017-0335-2_2

Verburg, P. H., \& Overmars, K. P. (2007). Dynamic Simulation of Land-Use Change Trajectories with the Clue-S Model. In E. Koomen, J. Stillwell, A. Bakema, \& H. Scholten (Eds.), Modelling Land-Use Change (Vol. 90, pp. 321-337). Springer Netherlands.

Verburg, P. H., Overmars, K. P., Huigen, M. G. A., de Groot, W. T., \& Veldkamp, A. (2006). Analysis of the effects of land use change on protected areas in the Philippines. Applied Geography (Sevenoaks, England), 26(2), 153-173. doi:10.1016/j.apgeog.2005.11.005

Verburg, P. H., \& Veldkamp, A. (2001). The role of spatially explicit models in land-use change research: A case study for cropping patterns in China. Agriculture, Ecosystems \& Environment, 85(1-3), 177-190. doi:10.1016/ S0167-8809(01)00184-0

Voinov, A., Costanza, R., Wainger, L., Boumans, R., Villa, F., Maxwell, T., \& Voinov, H. (1999). Patuxent landscape model: Integrated ecological economic modeling of a watershed. Environmental Modelling \& Software, 14(5), 473-491. doi:10.1016/S1364-8152(98)00092-9

Wang, S.-H., Huang, S.-L., \& Budd, W. W. (2012). Integrated ecosystem model for simulating land use allocation. Ecological Modelling, 227(0), 46-55. doi:10.1016/j.ecolmodel.2011.12.009

Wassenaar, T., Gerber, P., Verburg, P. H., Rosales, M., Ibrahim, M., \& Steinfeld, H. (2007). Projecting land use changes in the Neotropics: The geography of pasture expansion into forest. Global Environmental Change, 17(1), 86-104. doi:10.1016/j.gloenvcha.2006.03.007

Weng, Q. (2002). Land use change analysis in the Zhujiang Delta of China using satellite remote sensing, GIS and stochastic modelling. Journal of Environmental Management, 64(3), 273-284. doi:10.1006/jema.2001.0509

White, R., \& Engelen, G. (2000). High-resolution integrated modelling of the spatial dynamics of urban and regional systems. Computers, Environment and Urban Systems, 24(5), 383-400. doi:10.1016/S01989715(00)00012-0

Wu, W., Verburg, P., \& Tang, H. (2014). Climate change and the food production system: Impacts and adaptation in China. Regional Environmental Change, 14(1), 1-5. doi:10.1007/s10113-013-0528-1

Xie, Y., Batty, M., \& Zhao, K. (2007). Simulating Emergent Urban Form Using Agent-Based Modeling: Desakota in the Suzhou-Wuxian Region in China. Annals of the Association of American Geographers, 97(3), 477-495. doi:10.1111/j.1467-8306.2007.00559.x

Yu, C. H., Chen, C. H., Lin, C. F., \& Liaw, S. L. (2003). Development of a system dynamics model for sustainable land use management. Journal of the Chinese Institute of Engineers, 26(5), 607-618. doi:10.1080/02533839. 2003.9670815

Yu, H., He, Z., \& Pan, X. (2010). Wetlands shrink simulation using Cellular Automata: A case study in Sanjiang Plain, China. Procedia Environmental Sciences, 2(0), 225-233. doi:10.1016/j.proenv.2010.10.027

Yu, W., Zang, S., Wu, C., Liu, W., \& Na, X. (2011). Analyzing and modeling land use land cover change (LUCC) in the Daqing City, China. Applied Geography (Sevenoaks, England), 31(2), 600-608. doi:10.1016/j. apgeog.2010.11.019

Zhan, J., Deng, X., Jiang, Q. o., \& Shi, N. (2007). The Application of System Dynamics and CLUE-S Model in Land Use Change Dynamic Simulation: a Case Study in Taips County, Inner Mongolia of China. Paper presented at the Conference on System Science,Management Science \& System Dynamics. 
Zhang, Q., Ban, Y., Liu, J., \& Hu, Y. (2011). Simulation and analysis of urban growth scenarios for the Greater Shanghai Area, China. Computers, Environment and Urban Systems, 35(2), 126-139. doi:10.1016/j. compenvurbsys.2010.12.002

Zheng, X. Q., Zhao, L., Xiang, W. N., Li, N., Lv, L. N., \& Yang, X. (2012). A coupled model for simulating spatio-temporal dynamics of land-use change: A case study in Changqing, Jinan, China. Landscape and Urban Planning, 106(1), 51-61. doi:10.1016/j.landurbplan.2012.02.006

Zhou, D., Lin, Z., \& Liu, L. (2012). Regional land salinization assessment and simulation through cellular automaton-Markov modeling and spatial pattern analysis. The Science of the Total Environment, 439(0), 260-274. doi:10.1016/j.scitotenv.2012.09.013

Zorrilla-Miras, P., Palomo, I., Gómez-Baggethun, E., Martín-López, B., Lomas, P. L., \& Montes, C. (2014). Effects of land-use change on wetland ecosystem services: A case study in the Doñana marshes (SW Spain). Landscape and Urban Planning, 122(0), 160-174. 